\title{
THE STUDY OF COMMUNICATIVE INTELLECTUALITY PLACE/ROLE IN THE EXPANSION OF GENERAL DOMAIN FROM THE PERSPECTIVE OF MODERN THEORISTS OF COMMUNICATION
}

\author{
Maryam Foroughi \\ Master of communication. Legal Medicine Research Center, Legal Medicine Organization, Iran \\ mforoghi@lmrc.ir \\ Nassim Majidy \\ Phd Communication, Islamic Azad University, Tehran, Iran.
}

\begin{abstract}
The main idea of the lack of a master and general plan concerning the status of rationality and its evolution was shaped as a communicative rationality in communication science. The communicative place rationality in the public domain from the perspective of modernity theorists is the basic question in this field. Procedure of the research is qualitative research method with qualitative analysis of Max Weber. The first step of the research is an overview of research topic, objectives, research methods and Statistical Society. The next step is a deep study in the evolution of history of ancient Greece, during the development of Christianity and the explanation of votes in the Christian era, the Enlightenment and the intellectual revolution. Also, entries on topics such as the definition of modernism and modernity that define the modern scientific achievements and the consequences of modernity and its crisis on modernity and rationality is studied in this research. Finally, the communicative rationality and rationalization of the development and differentiation and achieve communicative rationality is deliberated. This section is fed mostly by Habermas's ideas and thoughts.
\end{abstract}

Keywords: Renaissance; Communicative Intellectuality; Domain; Perspective; Habermas's Ideas

\section{INTRODUCTION}

Revival/Renaissance

Renaissance in English, or the era of Rebirth was an important cultural movement that became the starter/starting point of a scientific revolution, religious reforms in addition to an era of artistic advancement in Europe. The era of Rebirth is a transit period in the middle ages and the new era. For the first time, the word Renaissance was used by the French people in the $16^{\text {th }}$ century. $14^{\text {th }}$ century is known as the beginning of Rebirth period in the north Italy. This movement also covered the north of Europe during $15^{\text {th }}$ century. Renaissance is a 300 years old evolution that was begun from the Florence and ended during the Enlightenment period in the Europe.

The Renaissance was started from Italy in 1300 and spread in the whole Europe during three centuries. It is very rare that a diverse and historical event could occur in such a short period. While these centuries are full of fundamental changes and great activities, the today's world is the aftermath of such activities, since the Renaissance founded the economical, political, artistic and scientific pillars of present civilizations in the Europe (Koric, 2005).

The knowledge and the art had brought the great advancements into existence in the Italy of $15^{\text {th }}$ and $16^{\text {th }}$ centuries. This cultural revival has become famous as Renaissance (i.e. Rebirth). Many scholars, composers and philosophers emerged who looked on the world with the newer oculus/eyes inspiring by the genuine heritage of Rome and Greece. Painters had engaged in the study of human body and painted the human body 
organs with a realistic method. The Rulers ordered the great artistic works and buildings. These fresh beliefs suddenly expanded in the whole Europe.

\section{Expression of communicative Views and beliefs during Renaissance}

1. German Emanuel Kant (1724-1804): considers the characteristic of this era the desire of human being to know the reality.

2. German Martin Luther (1929-1968): protested against the abuse/exploitation of church. We see the enlightenment of Protestant on its continuation.

3. John Lock (1632-1704): one of the other pioneers/pathfinders of this revolution founded the intellectual foundation of enlightenment through his theories and writing works. In view of Lock, all human beings have the power of thinking and the intellect itself shows that all human beings enjoy similar natural rights for desiring the life freedom and proprietorship.

4. Rene Descartes (1596-1650): was one of the most respectful supporters of intellect and used something similar to mathematical logic to find the reality.

A fresh wave of thinkers and writers emerged during the middle of the $18^{\text {th }}$ century whose viewpoint was different with the older speakers of enlightenment movement. These modern social critics had no further delusion about intellect.

They considered the cause of many social complications in the unlimited relying on intellect; several of the influential thinkers and writers had role against the intellect whose most powerful is the Jan Jack Russo.

The enlightenment period despite its abundant achievements passed and during the next century encouraged the criticisms in the context of Votes rights and world opinion. Many of the interpreters have blamed the philosophers that had caused the activating of rioting force that demolished the traditional sources of power, stability and discipline. Some of the critics proclaim that the enlightenment caused the existence of hopelessness, being without goal and solitude that is the characteristic of modern era. They argue that the enlightenment has an unlimited emphasis on the individual rights in place of the individual responsibilities and social obligations. Besides this, the philosophers were blamed for weakening the religion power and trust in God without showing any substitute for responding to the spiritual/religious needs of most people. The heritage of enlightenment has also made the environment supporters unhappy who say the emphasis on the advancement and intellect in the effective materialistic approach has been effective in encountering the nature world. (Machiavelli book and the Renaissance thought by Jahanbagloo (1991).

\section{INTELLECTUAL REVOLUTION OF DESCARTES}

One of the intellectual revolutions was started by Descartes; Descartes replaced the human intellect in place of sacred book and tradition of Pope, church and ruler. Descartes created a great topic with this step. Western Europe eliminated the philosophy of Descartes and the era of "Bright and distinctive thoughts" started, everything was measured and weighed by the criteria of intellect; even the contents of sacred bible in the belief era gave its place to the era of intellect. The method of Descartes for research on nature was inferential and suppositional.

\section{Modernity}

Until now, diverse definitions have been made of modernity and the extracts of word "modern", however these definitions have in no sense, eliminated the complexity from the actual concept of these words, or even increased the intricacy of it. The word modern that is equally used in all European languages and many of the other languages including Persian, has its root in Latin word "Modernus" that is extracted from the word "Modo." In the Latin language, the word 'Modo' means, recently, lately and very near past. A few of the history writers suggest that, the word Moderni, was used by Romans at the end of $5^{\text {th }}$ century about values and the new distrustful beliefs; the words which were in comparison with the ancient accepted beliefs which were specified by the word "Antiqui." 
Modernity that was considered the intellectualism period in the world of intuition/observation and disconnected from the invisible world with the exploitation goal, scientism, materialism and the thought of linear advancement, has transformed the life structure, human relationship as well as the comprehension of the modern man. (Ahmadi, 1998)

\section{Study of modernity concept from Jurgen Habermas viewpoint}

Habermas in the definition of new and modern word emphasizes on its relation with the past and knows the traditional past and the awareness resulted from living in the new and modern period to an ancient pattern in the past and the necessity to transit from it as well as applying the modern pattern: "the term of modern with different meanings and concepts, repeatedly expresses the awareness with an era or a period that connects itself with traditional past so that could regard itself the result of transit from the old to the new...in other words, the term of modern emerged and reemerged accurately during a period in the Europe that in which the awareness in relation with modern era took shape through the revival of relationship with the ancient people (Habermas (2005), Tadin (2005), Nozari (2002)).

Habermas considers the romantic soul of $19^{\text {th }}$ century resulted from the core of idealized middle ages that intensified the modernity awareness and turned it to a form of radical awareness. However, he considers this comparison between tradition and present as an abstract comparison.

In the words of Habermas, the intellect resulted from the enlightenment lies in three domains: first domain is the field of science whose logic is the instrumental intellect not the communicative intellect. Second field is the domain of ethics whose reliability is taken from the norm while the third domain relates to the art that is fed by the beauty. From the viewpoint of enlightenment thinkers, these three domains can cause the freedom of humankind and reduce the depth and the extent of existing problems and this is a defendable project. In the view of Habermas, being in line with the specializing of these three domains, they detached from everyday fields. For instance, in the domain of art, the art not with goodness but interpreted with the reliability of a climax inside its own or art for art only. Therefore, for liberation, the mentioned three domains should coordinate with each other and the modernity has the power and ability to be the caller of liberation (Habermas, 1998).

\section{Intellectuality and Modernity}

After passing the middle ages in Europe and entering into modernity, in general, an idea was discussed by Descartes as the main theory of modernity and this was the idea that in contrary to the middle ages that was the main factor tradition and introducer of world to the mankind, after that the man itself became the introducer of world and nature as well as the concepts around the western society. This idea became the background of all evolutions of this era in the west.

But this was not the only stroke to the modernity thought but after a while the realities of the world and the modernistic look to the world was also challenged by Marx.

Modernity became the main discussion of the sociology. The previous social theorists despite that had the more complex and more impartial perceptions on human situation. They in general, had less absorbed by the inevitable optimistic views in the human advancement through intellectual rationalism (Mohammadi (2001) and (2003)).

\section{Modernization as the intellectuality}

During the Renaissance the initial signs of modernity revealed a concept of extended rationalist 'Hmanism'. The goal was to increase the tolerance and intellectuality in all aspects and to achieve this goal they supported a necessary opposition for role playing. The tradition could not further be a justification for the human acts. The human world must be considered in the center of focus with certainty and the main objective should be the speculation, the change of religious state and speculating on the reality of Lord and his will. The needs, powers and the human interests should be the base and foundation of all values, and the social life should be 
changed based on these instances. Therefore, the human life should be organized only through logic: the movement should be towards a society where the rule of intellect and logic should replace the rule of Lord. Limiting the rationalization as the instrument to provide more satisfaction should be seen in the human life affairs. The Renaissance struggled against the absolute affairs of middle ages called the absolute skepticism and encouraged the doubt and misgiving. The fundamentals and the structures of mental proclaim that had advanced in the enlightenment process, its theorist was Marx Webber, who objective was to describe and interpret the rationalization in the communities of Europe which had also transferred to the other parts of the world. Weber rejected the beliefs of the theorists who saw the growth of rationalism as the inevitable result of a direct and global process of social evolution (Pooladi 2004).

\section{CONCEPT OF INTELLECTUALITY IN THE THOUGHTS OF MAX WEBER}

The targeted intellectuality mainly by applying the best possible under possession tool follows its fixed objectives. Webber believes that this type of intellectuality has dominated the western culture and the valued intellectuality has lost its color. However, regarding these two types of intellectualities does not take one sided stand. Therefore, we cannot recognize Webber as the herald thinker of intellectuality and intellectualism.

Webber with a historical viewpoint tries to analyze the nature of modern social life and notices in this framework that a type of being intellectual in the sense of very instrumental intellectuality has influenced the direction and dimension of human society during the history span especially in the modern era, specifically in the West where the intellectuality could come in to existence in this form of foundations such as modern state (discussed in the framework of Bureaucracy), capitalism economy and in the formation of modern rights.

Roger track rightly believes that the intellectuality problem, challenges the scholars of social sciences at two levels, the intellectuality manner of under study individuals is an issue, while the intellectuality of the scholars of social sciences is another problem (Cooke, 1994).

If we would have comprehended this separation in right way, the intellectuality of first type dates back to the intellectuality of the actions of actors while the second type of intellectuality to its standard, as scientist accept and love the scientism of social sciences. This is an important separation; of course it was also under consider in the discussion of Kent and Part, and presented their theories on this base. However, later on we would focus a serious attention to it (Habermas (2005)).

\section{INTELLECTUALITY}

This concept has had abundant applications, has been used in different areas. That is why, it has distinctive meanings. Perhaps by inducting the areas in which the word of intellectuality has been used, a comprehensive meaning could be taken in to consideration for it. This comprehensive meaning could be considered as the complete following of correct argumentation. It is clear that arguing on one thing has different ways that is why the intellectuality resulting from different types of argument would also be different.

Intellectuality is divided into theoretical and practical intellectualities in an initial classification. The theoretical intellectuality discusses the beliefs and world sighting while the practical intellectuality considers the actions and behaviors. Some have defined these two in this way: the theoretical intellectuality expresses more accurate mastery or domination on reality through the abstract concepts while the practical intellectuality means the probably more accurate calculation of the means to achieve a goal.

However, the ethical intellectuality of man is called by justice and equality and asks him not to oppress the others in pursuing ones goal and don't sacrifice their rights for him. Summarily, this intellectuality for pursuing the personal interests specifies the framework that is the very boundary of ethical and moral values.

Intellectuality's concept and being Normative

Submit Date: 10.05.2016, Acceptance Date: 25.06.2016, DOI NO: 10.7456/1060JSE/036

Copyright (C) The Turkish Online Journal of Design, Art and Communication 
The Turkish Online Journal of Design, Art and Communication - TOJDAC July 2016 Special Edition

A normative definition is made in defining the intellectuality. Intellectuality is an abstract concept extracted from the adjective of intellectual. We are compelled to investigate this trait to define intellectuality.

\section{Instrumental Intellectuality}

Dominant thought in the framework of intellectuality based on the theory of intellectual selection focuses and emphasizes on the instrumental intellectuality and the result logic. Based on this approach, the actors think about the result of their selection and deal with the decision making by analyzing cost and profit.

The instrumental intellect orders that the best and the cheapest tool should be applied to achieve the most profitable objectives. If the selection of optimal option in the sense of absolute intellectuality is not available, the choosing of a cheaper option is equal to the inevitable limited intellectuality. The criterion of intellectuality is the success rate in acquiring the interests/profits and developing the desired results. This type of intellectuality is called instrumental intellectuality.

\section{Moral Intellectuality}

Other type of intellectuality is the moral intellectuality. The moral intellectuality is necessary with the proportion logic and focused on the specification and determination of duty or obligation as well as decision making and the appropriate action to it.

\section{Communicative Intellectuality}

Other type of intellectuality is known as the communicative intellectuality.

As per the view of Habermas the relation through tongue necessarily needs the posing of reliability claim specifically the reality of truth fact whose situation at the time of views difference could only be solved through conversation/discussion. Besides that Habermas believes that the native of a language completely recognizes the conditions of such conversation that brings actually the positive results and he has explained these conditions in terms of attributes of justifying and idealistic traits of speech. The communicative intellectuality, implies on this point that the man/humankind has this ability that he engages in protest in the conditions close to this idealistic situation ('discourse' as per Habermas term) and with the goal of access to agreement.

Habermas relies on the concept of intellectuality so that to describe this point whatever is shown by the democratic forms of social organization, is more beyond the very priorities in the cultural and political tradition. In his view, the speech action cannot be even understood without adopting the stand regarding reliability claim that he discusses and this stance itself prepares for the conversation free from limitation that situation specifies (this) claim. Therefore, the social and political arrangements can be criticized, because as per the outlook of Habermass, that reaching the agreement is either a goal that is the personal object for human tongue. A same philosophical program has also been discussed by Karl Otto Opal; he more emphasizes on the glorification traits of protest.

Habermass makes clear that the participants in the communicative action should see the statements discussed during conversation from the viewpoint of their reliability, and also should have full cognition in the context of appropriate ways to solve the difference instances on the claim of credibility as well as in the context of the conditions (that is always against reality) in which the following up of such methods would actually give the correct result. For instance, the pursuance to imposing the hidden pressure makes previously obtained agreement unreliable, this cognition becomes mobilized. The comparison base between instrumental and communicative intellectuality that indicates the endeavor of Habermas in the direction of treating this situation is in the philosophical anthropology which has been presented systematically in the 'cognition and the human interests' (Habermas 1981). Habermas suggests here that every society for its reproduction should be powerful on the exchange of generator/producer with nature (in the work form) in addition to the communicative coordination of the collective activities. Work creates the concepts that express the 'technical interest' to 
instrumental control, while the need to agreement creates the framework of distinctive category and practical interest to the hermeneutic understanding (Habermas, 1988).

Habermas replaces the theory of discoursing reality with the theory of conformation reality. While, the second theory was challenged by the Cartesian science of criticism's subjectivity and the text free intellectuality. Habermas claims that the first theory which refreshes itself with every communicative action can save us from the morass of relativism.

Habermas applies the interpretation of general domain in attributing to the social area in which the individuals produce the stances and valued and normative orientations through mutual understanding and argumentation based on thinking and in the conditions free from every type of pressure, force and under equal conditions for all sides of participants of behavior collection, stands and valued as well as normative orientations.

What has caused the attracting of Habermas' view to the topic of general domain has been the importance of this title as the criticism base of society, based on democratic principle. The general domain is the area in which the individuals get together to participate in the open and free discussions. In view of Habermas, the general domain in the accurate sense of words is an area that no limit and constraint would have been enacted on its activity. The general domain is the intellectual, fact finding and reality making domain of the society.

Habermas is following the revival of general domain by creating and expanding the theory of communicative action. The intellect discussion (conversation) free of domination and the linguistic damages and agreement and consensus is the very local type that is appropriate for general domain. In the view of Habermas, the theory of communicative action can be applied as the fundament of general principle.

The communicative action has a social situation. In the communicative action the agent/operant person has no weapon except logical argument. Human beings can access the agreement and correlation more freely and easily without direct distress and indirectly the necessary material problems in a process of view exchanging. The objective of such social action is the cognition of all and accepting the same realities. This domain in fact is a social ideal.

Answers are not ready in priory but the people select their ways by view exchanging and criticizing them. In the communicative action, the participants exceed their cooperation and there are no more mathematically dry calculations as well as the pre-existing pressure but people try to select the ways for agreement through discussion and conversation. This action is liberating intrinsically, because it accompanies high actions. This liberation could materialize in a bad and ground in which the self recognition would be possible through discourse. (Habermas, (1976))

Habermas believes that the theory of being intellectual of Weber enjoys significance to understand the modernity that is the fundamental issue. We follow the modernity issue/problem through the works of Max Weber since his 'errors/ mistakes' are considered the visualization of intellectual and practical indigence/helplessness in facing our own period.

On the other hand, we are fully satisfied that transit from the traditional societies to our present societies is equal to liberate from magic and sorcery, and has been from several types of sacred dread that provided the arrangements to investigate the beliefs, unhappy end of Galileo as well as the Sorcerers of Salem, this advancement is known as intellectual progress alongside the science evolution. Weber names this advancement the process of 'incantation and de-hallucination.'

On the other hand, when we look on our own period with keen eyes, undoubtedly we see everything completely different. All of a sudden the advancement changes to the growth of independent half of science 
and technology, takes control of our reign and crosses us through a path that Habermas, the process that pulls us directly to the 'iron cage' of recent capitalism.

The problem lies here; Habermas tries to give a compromise between two process of sorcery and dehallucination in a single theory of modernity and the modernization. To do this in appropriate way, it is necessary to reconstruct the theory of Weber, the reconstruction that could analyze the theory in separate components and collect it in a modern form to reach the goal the theory accepts for itself in a complete way.

In the modern sociology, four types of intellectuality have been introduced by model making of Max Weber's theory. These four species as per Kleberg are as follows: theoretical, practical, intrinsic and external (structural).

In contrary, Habermas presented the new classification of intellectuality. He suggests that we face two categories of intellectuality, first the instrumental intellectuality that in his words, all endeavors of Weber had been passed in explaining such type of intellectuality. Other, is the cultural-valued intellectuality focused on the goals of actions. The cultural-valued intellectuality watches the correction of communicative actions; this process is possible through independent and logical discourse (Habermas, 1988).

Habermas identified two types of intellectuality in the Weber works: one the cultural-valued intellectuality and the other, official or instrumental intellectuality. Habermas believed that the cultural-valued intellectuality remained incomplete in the thoughts of Weber; however, the instrumental intellectuality has been much expanded in the theories of state, economy and Bureaucracy. Habermas tries to explain the first process of intellectuality. At the same time, he sees a dialectical relationship between these two processes of intellectuality.

The valued cultural intellectuality lies in the center of special type of action that is interpreted as communicative action by Habermas. In the communicative action of discourse or the speech relationship that is accomplished by means of tongue, identified as the characteristic of intellectual concept among the actors. Habermas before introducing the communicative action explains two types of actions i.e. 'instrumental action' and 'strategic action' in a size that helps the expression of communicative action. These two actions lie under the umbrella of instrumental intellectuality that follows a reasonable instrument to reach the given objective. Though, the instrumental action is intellectual but considered as individual that resembles the "practical intellectuality.' Contrarily, the action is a collective strategy that is followed by social structure or organization. Bureaucracy or the structure of modern society is administered based on the strategic action that is the very example of high instrumental intellectuality. Habermas, in contrary to these two, puts a communicative action that is social firstly; secondly it is intellectual in terms of goal and end; because, the goal choosing in this action takes place based on discussion and free discourse, as well as intellectualism that has been freed from all types of structural and political domination.

Contrary to the reasonable and targeted action whose main orientation is formed by accessing the opportunistic success, the communicative action and communicative intellectuality have the orientation of understanding. Therefore, the actions of the related persons, are coordinated not through opportunistic success calculations, but through the comprehensible actions. So, the engaged people in communicative action are not restricted to personal success but follow their goals under the conditions in which they could coordinate their action plans based on a definition of 'common success.' Habermas defines the action and the communicative action in this way: the communicative action implies the interaction of at least two factors which are able to speak and establish the personal relations. He names the Webry rationalism as instrumental intellectuality.

This could be said on the viewpoints difference of these two:

The valued intellectuality of Habermas is focused on the correction and reconstruction of the goals and societal values; while, the instrumental intellectuality is focused on optimizing the methods and the means. 
The Webry intellectuality often notices the individual actors as well as the sharp action of them, while the valued intellectuality also emphasizes on the social and structural dimension.

In the instrumental intellectuality only the reasonability and being targeting of action has importance while in the valued intellectuality, the communicative action and the distorter/falsifier factor is also under consideration. In view of Habermas the intellectuality is a norms giving instrument, obligatory and arising from the social system especially in the form of formal intellectuality that is imposed on the actors. While the intellectuality is a value based on free discourse and far from domination and its result is the common and collective agreement. (Adorno and Horkheimer, 1944).

\section{FALL OF GENERAL DOMAIN AND COMMUNICATIVE INTELLECTUALITY}

However, the Habermas refers to the attenuation manner of general domain and believes that the state interference, part politics and the manipulation of mass media weakens the general domain and the general domain and the communicative intellectuality changes to an ideological element. Habermas believes that the cause of the genuine democratic debate's fall is considered a role played by the monopoly mass media in keeping the general public unaware and optimist.

If the general domain goes under the domination and the control of a number of organizations and the powerful giant establishments, this domain would change to a mean and instrument for manipulating the general interests and the minds and each and every particular beneficiary group by accessing the mass media means, tries to demonstrate its specific interest as the general interest that this confusing effect taking is considered as one of the traits of autocrat and authoritative governments which easily turn the people to the tractable herds. Therefore, the interference in general domain is one of the pillars of power seeking governments. (Habermas, 1988).

\section{Habermas under Critics}

From the very beginning of inserting and resulting of communicative intellectuality theory of Habermas, this theory and its theorist went under the fire of a number of critics that the following instances could be named in this regard:

1. The moral theory of Habermas in the real sense is a 'monologue.' The reason is that the mentioned credibility giving conversation the conversation moral relies on is an idealistic dialogue, not a real conversation. In the real life, the idealistic situation of speech as well as the speech of Habermas never materialized completely, and possibly would never be materialized in the future, even if its reason is its time limitation. Besides that, the group of people who are exposed to the effect taking of a norm they must agree upon it, possibly includes the people who have not still born in this world. Therefore, it is always possible for Habermas that he does not accept the agreement conditions that have been obtained in the real dialogue. If we are set to put the dialogue moral in practice, the moral factor can only conclude that which type of agreement is achieved in the idealistic dialogue. Such thing is only the arrangement of discovering and exploring that could only be used in the memory of a scholar i.e. in the monologue form (Nozari, 2002).

2. Habermas uses the psychoanalysis as a model to express the concept of liberating social science; however the treatment relation is different from that of actual social condition. In the treatment relation, on one side the voluntary relationship obeys the other, but in the social contradictions we always encounter the situation of two sided resistance.

3. This shaping of Habermas is of limited significance from the sociological viewpoint. Because it not sufficiently general and has its roots in the awareness philosophy more than needed and has been tied with a picture of an individual and sole speaker and listener and does not include the oral society.

4. Finally, whether the communicative intellectuality of Habermas is beyond the instrumental intellectuality, i.e. not an appropriate selection as means-goal. Finally, the dialogue is also a means for achieving a given objective.

5. The shaping or formulating of intellect in the world of humanitarian sciences relying on the using methods of empirical science is included in the discussions that have been under serious and grave

Submit Date: 10.05.2016, Acceptance Date: 25.06.2016, DOI NO: 10.7456/1060JSE/036

Copyright $(\odot)$ The Turkish Online Journal of Design, Art and Communication 
critics of Habermas. On one hand, passing through the instrumental intellectuality positivistic and targeted forms, towards the communicative and conceptual intellectuality that is based on the sound and liberating human actions. On the other hand, the exit or the Go out from the degeneracy (iron cage) of capitalism's intellectuality is considered as the theoretical approach of this political thinker/philosopher.

6. Opal prefers the term of "lofty pragmatics" on "global pragmatism" of Habermas for the general theory of communicative skill. The main differences between Opal and Habermas, dates back to their attitude on the possibility of "Letzt begrundung" (last argument) for moral and combative/Jihadist stance. Apel (1990) in a critical article stated that Habermas mistakes who underestimates the (lofty difference) between the reconstructions of communicative skill that has the ability of empirical test and philosophical deliberation, the deliberation that reveals the unconditional credibility of some basic presumption of protest.

Summarily and generally, we have compiled the theories inference of the theorists regarding the intellectuality in the form of a progressive table.

\begin{tabular}{|c|c|c|c|c|}
\hline Theorist & $\begin{array}{c}\text { Attitude and type of belief to } \\
\text { intellectuality }\end{array}$ & $\begin{array}{l}\text { Under study } \\
\text { elements }\end{array}$ & $\begin{array}{l}\text { Approa } \\
\text { ch } \\
\text { (positiv } \\
\text { e, } \\
\text { negativ } \\
\text { e) }\end{array}$ & $\begin{array}{l}\text { Material/non } \\
\text { material } \\
\text { viewpoint }\end{array}$ \\
\hline $\begin{array}{l}\text { Modernizati } \\
\text { on }\end{array}$ & $\begin{array}{l}\text { Revealed the initial signs of modernity } \\
\text { for vast humanism concept of } \\
\text { rationalism }\end{array}$ & Humanism & Positive & $\begin{array}{l}\text { Non material } \\
\text { (tolerance } \\
\text { along with } \\
\text { intellectuality) }\end{array}$ \\
\hline Kant & $\begin{array}{l}\text { Intellect and mind/brain have prior } \\
\text { molds, the sensing experiences of it are } \\
\text { inserted in it and intellectualism shaped } \\
\text { considering the structure and culture }\end{array}$ & Fact finding & Positive & $\begin{array}{l}\text { Material } \\
\text { (print) }\end{array}$ \\
\hline Luther & $\begin{array}{l}\text { Contradiction of intellectuality by fully } \\
\text { accepting } \\
\text { It in all issues especially the religion }\end{array}$ & $\begin{array}{l}\text { Religion and } \\
\text { intellectuality }\end{array}$ & positive & $\begin{array}{l}\text { Non material } \\
\text { (Religion } \\
\text { protestant) }\end{array}$ \\
\hline Lock & $\begin{array}{c}\text { All humankind have intellect ability and } \\
\text { the intellect itself indicates the enjoying } \\
\text { of similar and natural rights of human } \\
\text { beings }\end{array}$ & Natural rights & positive & $\begin{array}{l}\text { Material, } \\
\text { freedom } \\
\text { demand, } \\
\text { proprietorship }\end{array}$ \\
\hline $\begin{array}{l}\text { Descartes/D } \\
\text { escart }\end{array}$ & $\begin{array}{l}\text { Intellect should be the commander/ruler } \\
\text { in place of Pope, tradition and Church }\end{array}$ & $\begin{array}{l}\text { Mathematical } \\
\text { logic }\end{array}$ & Positive & $\begin{array}{l}\text { Non material } \\
\text { (replacement of } \\
\text { intellect in } \\
\text { place of Sacred } \\
\text { book) }\end{array}$ \\
\hline Russo & $\begin{array}{l}\text { Humankind advancement without } \\
\text { morality and creation of unlimited power }\end{array}$ & $\begin{array}{l}\text { Morality in place } \\
\text { of intellectuality }\end{array}$ & $\begin{array}{l}\text { Negativ } \\
\mathrm{e}\end{array}$ & $\begin{array}{c}\text { Material. } \\
\text { Believing in } \\
\text { natural } \\
\text { freedoms and } \\
\text { sensational and } \\
\text { instinctive }\end{array}$ \\
\hline Weber & $\begin{array}{c}\text { Believes in three types of } \\
\text { intellectualities: valued, targeted and } \\
\text { instrumental intellectualities. by applying } \\
\text { the best tool best goals are accessible }\end{array}$ & $\begin{array}{l}\text { Instrumental } \\
\text { intellectuality }\end{array}$ & positive & $\begin{array}{l}\text { Material (being } \\
\text { professional, } \\
\text { work }\end{array}$ \\
\hline
\end{tabular}




\begin{tabular}{|c|c|c|c|c|}
\hline & $\begin{array}{c}\text { (Webbers' intellectuality is used as the } \\
\text { axis of historical evolution) }\end{array}$ & & & distribution) \\
\hline Roger Track & $\begin{array}{l}\text { Intellectuality problem should be studied } \\
\text { based on the intellectuality manner of } \\
\text { individuals and investigated based on the } \\
\text { intellectuality of the scholars itself }\end{array}$ & $\begin{array}{l}\text { Individual and } \\
\text { active } \\
\text { intellectuality }\end{array}$ & Positive & Non material \\
\hline $\begin{array}{c}\text { Kent } \\
\text { Kindersley }\end{array}$ & $\begin{array}{l}\text { He believes that man is an entity, } \\
\text { sentimental, intellectual and with arguing } \\
\text { power; he has divided the morality ideas } \\
\text { of human advancement into } 10 \text { elements } \\
\text { and assigned the } 10^{\text {th }} \text { era to intellectuality }\end{array}$ & $\begin{array}{l}\text { Improvement and } \\
\text { morality }\end{array}$ & Positive & Non material \\
\hline Fuchou & $\begin{array}{l}\text { Believes the emergence distinction } \\
\text { between intellect and non intellect } \\
\text { (believes in Webry intellect) } \\
\text { Believes in the concept of Episteme: is a } \\
\text { set of relations that unites the characters } \\
\text { of existing discourse, knowledge, } \\
\text { sciences and intellectual systems }\end{array}$ & $\begin{array}{l}\text { Scientific/knowle } \\
\text { dge insanity }\end{array}$ & Positive & $\begin{array}{l}\text { Material } \\
\text { (objectivity } \\
\text { giving to } \\
\text { discourse) }\end{array}$ \\
\hline Prato & $\begin{array}{l}\text { Behavioral and or communicative } \\
\text { intellectuality is that in which the goal of } \\
\text { subject is related to the required goal of } \\
\text { receiver/acceptor and believes that the } \\
\text { intellectual action is an action that should } \\
\text { enjoy similar and same meaning in terms } \\
\text { of objectivity as well as intellectuality } \\
\text { and mind. }\end{array}$ & $\begin{array}{l}\text { Intellectual View } \\
\text { with the context } \\
\text { of sciences } \\
\text { context }\end{array}$ & Positive & $\begin{array}{c}\text { Material } \\
\text { Webry } \\
\text { intellectuality }\end{array}$ \\
\hline Bowdon & $\begin{array}{l}\text { He believes that some short term } \\
\text { intellectual actions become non } \\
\text { intellectual during long periods }\end{array}$ & $\begin{array}{c}\text { Logical } \\
\text { intellectuality }\end{array}$ & Positive & $\begin{array}{c}\text { Material } \\
\text { (Webry } \\
\text { intellectuality) }\end{array}$ \\
\hline Marx & $\begin{array}{c}\text { Severely attacks the modern } \\
\text { intellectuality, he believes up to some } \\
\text { extent to the Descartes intellectuality and } \\
\text { believes that intellect causes the } \\
\text { domination/control }\end{array}$ & $\begin{array}{l}\text { Domination of } \\
\text { intellect }\end{array}$ & $\begin{array}{c}\text { Negativ } \\
\mathrm{e}\end{array}$ & non material \\
\hline Hosrel & $\begin{array}{c}\text { Agree with being Nihilist of modern } \\
\text { intellectuality and became closed to the } \\
\text { Nihilism }\end{array}$ & Nihilist & $\begin{array}{l}\text { Negativ } \\
\mathrm{e}\end{array}$ & non material \\
\hline Heidegger & $\begin{array}{l}\text { Usually believes in the intellectuality } \\
\text { required by Hosrel }\end{array}$ & Direction changer & $\begin{array}{c}\text { Negativ } \\
\mathrm{e}\end{array}$ & non material \\
\hline Hegel & $\begin{array}{l}\text { Believes intellect evolution during } \\
\text { historical stages and what is the fact and } \\
\text { materialized is the intellectuality and } \\
\text { what is intellectual is a reality }\end{array}$ & Reality & Positive & material \\
\hline Habermas & $\begin{array}{l}\text { He as well as believes in the Webry } \\
\text { intellectuality and on the other hand the } \\
\text { intellectuality from his view is different } \\
\text { in the Hegel's concept }\end{array}$ & $\begin{array}{l}\text { Communicative } \\
\text { intellectuality and } \\
\text { communicative } \\
\text { action }\end{array}$ & Positive & non material \\
\hline Nietzsche & $\begin{array}{l}\text { He was Desirous of radical and } \\
\text { fundamental criticism of modern }\end{array}$ & $\begin{array}{c}\text { Domination of } \\
\text { slavery on moral }\end{array}$ & $\begin{array}{l}\text { Negativ } \\
\mathrm{e}\end{array}$ & non material \\
\hline
\end{tabular}




\begin{tabular}{|c|c|c|c|c|}
\hline & $\begin{array}{c}\text { intellectuality as well as modern } \\
\text { civilization; the criticism that shaped } \\
\text { from inside and considered as most } \\
\text { fundamental critics }\end{array}$ & intellectuality & & \\
\hline Deltai & $\begin{array}{l}\text { Is void of modern intellectuality; since } \\
\text { he also criticizes the descartes-Kanti's } \\
\text { intellectuality. From the perspective of } \\
\text { Deltai the intellect of Descartes and } \\
\text { Kanti are non-historical and believes that } \\
\text { the modern intellectuality wants to } \\
\text { understand all things in the framework of } \\
\text { objective classes/categories }\end{array}$ & $\begin{array}{c}\text { Interpreting } \\
\text { method }\end{array}$ & $\begin{array}{c}\text { Negativ } \\
\mathrm{e}\end{array}$ & non material \\
\hline
\end{tabular}

\section{REFERENCES}

Adorno, T.W., Horkheimer, M., Dialectic of Enlightenment, London: Verso, 1979.

Ahmadi, B., puzzle of modernity, Tehran, Markaz publication, 1, 1998.

Apel, K.O., Transformation der Philosophie., Sprachanalytik, Semiotik, Hermeneutik. Das Apriori der Kommunikations gemeinschaft, Frankfurt: Suhrkamp Verlag, 1976. (Toward a Transformation of Philosophy, London: Routledge 1980, reprinted by Marquette University Press 1998.)

Apel, K.O., Is the Ethics of the Ideal Communication Community a Utopia?, In: S. Benhabib \& F. Dallmayr (ed.): The Communicative Ethics Controversy, Cambridge, MIT Press 1990, 23-60.

Brandon, H., The retreat of American power, Translated by Tadin A., Hormoz publication, Tehran, 2005. Cooke, M. Language and Reason: A Study of Habermas' Pragmatics, Cambridge MA: MIT Press, 1994.

Habermas, J., Eine genealogische Betrachtung zum kognitiven Gehalt der Moral, in: Die Einbeziehung des Anderen. Studien zur politischen Theorie, Frankfur, Suhrkamp 1998, 11-64.

Habermas, J., Kommunikatives Handeln und detranszendentalisierte Vernunft. Stuttgart: Reclam 2001. Habermas. J., Theory of communicative action, translation by Kamal Pooladi, Tehran newspaper publications: Tehran, 2005.

Koric J. A., Renaissance translated by: Azita Yasaei, Tehran: Ghaghnous publication, 2005. ISBN 964-311323-X

Mcyaweli, M., Book of and Thought of Renaissance by Ramin Jahanbugloo, Markaz publication, 1991.

Mohammadi R, study on sociology of intellectuality, Baz publication, Tehran, 2001

Mohammadi R, prelude on the sociology of intellectuality, Baz publications, Tehran, 2003.

Nozari, H., Review of Habermas, Chashmeh publication, Tehran, 2002.

Pooladi M, History of political thought in the West, $20^{\text {th }}$ century, Markaz publication, Tehran, 2004. 